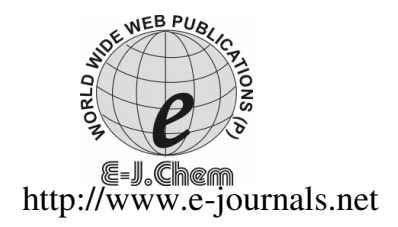

ISSN: 0973-4945; CODEN ECJHAO

E-Journal of Chemistry 2011, 8(2), 629-634

\title{
Small Dumbbell Oligonucleotides Inhibitors of RNase H Activity of MOMULV Reverse Transcriptase
}

\author{
AJAY KUMAR \\ Apeejay Stya University \\ Palwal Sohna Road, Gurgaon, Haryana, India \\ ak.gupta59@rediffmail.com
}

Received 5 June 2010; Accepted 26 August 2010

\begin{abstract}
The small dumbbell oligonucleotides containing loops of phosphodiester (OL-1), two trimethylene, $\mathrm{C}_{3}$ moieties in each loop (OL-2) and phosphorothioate (OL-3) linkages were synthesized. Incubation of OL-1 and OL-2 with S-1 nuclease generated break down products whereas incubation of OL-3 did not result in significant cleavage. Their binding to moloney murine leukemia virus reverse transcriptase was evaluated by PAGE band mobility shift assays. The OL-3 bound more strongly to the reverse transcriptase than OL-1 and OL-2. The dissociation constants evaluated using PAGE band mobility shift assays were of the order of $10^{-7}$. Investigation of inhibition of RNase $\mathrm{H}$ activity of reverse transcriptase showed that the OL-3 is a better inhibitor of the retroviral RNase $\mathrm{H}$ activity than both OL-1 and OL-2. Thus OL- 3 may be used as RNase $\mathrm{H}$ inhibitor. Our studies demonstrated that this particularly designed oligonucleotide (OL-3) displays an $\mathrm{IC}_{50}$ of $25 \mathrm{nM}$ in its inhibition on the reverse transcriptase RNase $\mathrm{H}$ activity, a magnitude lower than that of first nucleotide reverse transcriptase of HIV-1, tenofovir, introduced by Gilead Science in the market.
\end{abstract}

Keywords: Small dumbbell oligonucleotides, MOMULV reverse transcriptase, Inhibition of RNase H activity of MMLV RT.

\section{Introduction}

Reverse transcription is a key enzyme for life cycle of retroviruses. It bears RNA and DNA dependent DNA polymerase activities. It also posses ribonuclease $\mathrm{H}$ activity. During reverse transcription of the viral genome, the RNase $\mathrm{H}$ domain of reverse transcriptase cleave the $t$-RNA Lys 3 primer required for minus strand synthesis, degrades the RNA templates during or after minus strand synthesis and removes the polypurine RNA primer during or after plus strand synthesis ${ }^{1}$. RNase $\mathrm{H}$ activities are prerequisites to the integration of the viral genetic information into the host cell genome. Therefore any ligand able to block the 
RNase $\mathrm{H}$ activity would prevent the development of retroviruses. However, up to now a very limited number of molecules have shown to display RNase $\mathrm{H}$ inhibitory properties ${ }^{2,3}$. There are several other published examples of HIV-RT inhibitors that block both DNApolymerase and RNase $\mathrm{H}$ activities. Among these is $N$-(4-tert- butyl benzoyl ) -2- hydroxy1- naphthaldehyde hydrazone $(\mathrm{BBNH})^{4}$ illimaquinone, a natural product of marine origin, which inhibits the RNase H activity of HIV-1 RT, MLV-RT and Escherichia coli ${ }^{5,6}$. Recently, a diketo acid, 4-\{5-(benzoylamino) thein -2-yl $\}-2,4$ - dioxbutanoic acid has been shown to bind RNase $\mathrm{H}$ domain selectively ${ }^{7}$. Also it has recently been shown that 18 base pair RNA/RNA and 2',5-RNA/RNA duplexes inhibited RNase $\mathrm{H}$ by competively suppressing binding of the DNA/ RNA substrate to HIV-1 RT ${ }^{8}$. These RNA/RNA and 2', 5'-RNA duplexes also hinder E.coli RNase $\mathrm{H}$ activity. But the free ends make them susceptible to degradation by ubiquitous cellular nucleases predominantly by 3'- exonuclease type ${ }^{9}$. Recently, it has been shown that small unmodified RNA hairpins and dumbbells can selectively inhibit the RNase H activity of HIV-RT without affecting other cellular RNase H (e.g. E. coli and Human RNaseH) and do not disrupt the DNA polymerase activity ${ }^{10}$. The inhibitory potencies of several hairpins comprising DNA, RNA and 2'-5' - linked RNA segment have shown that hairpin structures having 3'-5'- linked rather than 2',5'- liked RNA loop are potent inhibitor ${ }^{11}$. Recently we have shown that hairpin oligonucleotides containing phosphorothioate linkage at 3'- loop inhibit RNase $\mathrm{H}$ activity of MML-RT with $\mathrm{IC}_{50}$ falling in the range of $140-150 \mathrm{nM}$.

The first oligonuclotide base drug entered into clinical trial in early 1990 was a 25 mer antisense PS-ODN ${ }^{12}$ second antisense oligonucleotide drug ${ }^{13}$ which entered in clinical trial contained mixed phosphotriester and phosphorothioate backbone. Both were discontinued. The first oligonucleotide therapeutics, Vitravene ${ }^{14}$ approved by United State FDA is a 21- mer PS ODN. Tenofovir disoproxil fumarate (Gilead) is a nucleotide analogue reverse transcriptase inhibitor used as $\mathrm{HIV}-1$ drug. In vitro tenofovir $\mathrm{IC}_{50}$ was in the range of 0.04- 8.5 $\mu \mathrm{M}$. The anti HIV-1 drugs used so far have shown various side effects. Patients who are taking anti-HIV drugs have suffered these drug toxicities for a long time. Dosages and combinations of drugs can be chosen so they don't kill the person, but they still can't be used at their most effective concentrations against HIV. Thus in order to develop more effective drug for retro virus infection we are investigating the binding and inhibitory properties of oligonucleotide with various chemistry to MOMULV Reverse Transcriptase. Although the catalytic activity of RNase $\mathrm{H}$ is restricted to RNA-DNA hybrids but enzymes can bind to different duplexes including DNA-DNA ones. As circular oligonuceotides display significant nuclease resistance ${ }^{15}$ they may be considered as good candidates to design RNase $\mathrm{H}$ inhibitors. Earlier we have reported binding of dumbbell oligonucleotides (containing $12 \mathrm{bp}$ duplex in the centre) with MOMULV Reverse Transcriptase ${ }^{16}$. In order to optimize length of central duplex of the dumbbell oligonucleotides, we synthesized dumbbell oligonucleotides containing $8 \mathrm{bp}$ duplex instead of $12 \mathrm{bp}$ duplex. We report here, data on the design of dumbbell oligonucleotides (containing $8 \mathrm{bp}$ duplex in the center) that aimed at inhibiting RNase $\mathrm{H}$ activity. The small dumbbell oligonucleotide containing phosphorthioate bonds in the loops displays an $\mathrm{IC}_{50}$ of $25 \mathrm{nM}$ in its inhibition on the reverse transcriptase RNase $\mathrm{H}$ activity. This magnitude is lower than that of first nucleotide reverse transcriptase of HIV-1, tenofovir, introduced by Gilead Science in the market.

\section{Experimental}

Moloney murine leukemia virus (MMLV) reverse transcriptase (RT) was purchased from Gibco -BRL. The concentration of protein, determined from its specific activity provided by 
the supplier, was 7.6 pmole $/ \mathrm{uL}$. The oligonucleotides $P$-CCTGTTTTTCAGGGA TTTTTTGTC and $P$-CCTGsTsTsTsTsTsCAGGGAsTsTsTsTsTsTsGTC were synthesized on Millipore Expedite synthesizer by standard phosphoramidite chemistry, s denotes phosphorthioate linkage. In oligonucleotide OL-2 two trimethylene, $\mathrm{C}_{3}$ moities were added in each loop respectively as described earlier ${ }^{16}$. A phosphate group was introduced at the 5'end by 2 (2'(4,4'-dimethoxytrityloxy) ethylsulfonyl) ethyl-(2-cyanoethyl)- $N, N$ '-isopropyl phosphoramidite. The phosphorothioate part of the chimeric oligonucleotide OL-3 was synthesized by oxidizing phosphite diester bond to phosphorothioate by Beaucage reagent ${ }^{17}$. The oligonucleotides were purified by electrophoresis on $20 \%$ polyacryamide gel containing $7 \mathrm{M}$ urea. The upper bands corresponding to the longest oligomer, visualized by UVshadowing were cut out. The gel pieces were socked in water : methanol $(80: 20 \mathrm{v} / \mathrm{v})$ overnight and volume was reduced to $100 \mu \mathrm{L}$. Finally, the oligonucleotides were desalted on a Sephadex G 50 Column. The synthesis of small dumbbell ologonucleotides was carried out as described earlier ${ }^{16}$. S1 nuclease treatment was also carried out as described earlier ${ }^{16}$. Polyacrylamide gel electrophoresis band mobility shift assays were carried out as described elsewhere ${ }^{18}$. The binding constant Ka was evaluated from the MMLV -RT concentration at which $50 \%$ of the oligonucleotide was converted into oligonucleotide/RT complex: Ka = \{MMLV RT $\left.50^{-1 / 2}(\mathrm{ODN})_{\mathrm{o}}\right\}^{-1}$. Where $(\mathrm{OND})_{\mathrm{o}}$ is initial oligonucleotide concentration and (MMLV RT) 50 is the enzyme concentration inducing 50\% band shift ( Figure 2). For the Inhibition of RNase $\mathrm{H}$ activity of MMLV Reverse Transcriptase the synthesis of ${ }^{3} \mathrm{H}-\mathrm{UTP}$ labeled RNA: RNA-DNA hybrid required for RNase $\mathrm{H}$ activity inhibition assay was prepared as described elsewhere ${ }^{19}$. Finally percentage RNase $\mathrm{H}$ inhibitions were plotted against oligonucleotides concentration (Figure 3).

\section{Results and Discussion}

The small dumbbell, OL-1 was prepared with two loops made up of 5 Ts containing phosphodiester bonds. The OL-2 was prepared with two loops made up of two C3 units and OL-3 was prepared with two loops made up of 5 Ts containing phosphorothioate linkages. The 3'-exonucleases are the most abundant DNases in biological media ${ }^{20}$ but OL-1 will still be degraded by endonucleases. Indeed, incubation of OL-1 and OL-2 with S1 nuclease generated breakdown products as seen by electrophoretic analysis on a denaturing polyacryamide gel. Incubation of OL-3 with S1 nuclease did not result in significant cleavage under conditions which led to degradation of OL-1 and OL-2 (Figure 1).

\section{Minutes}

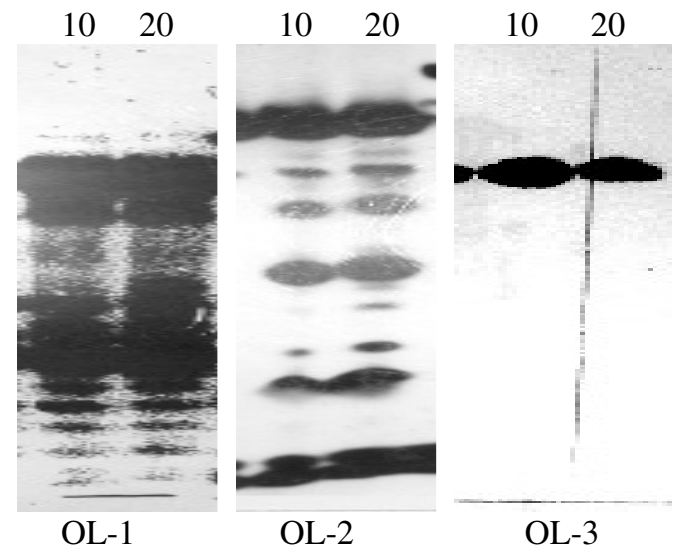

Figure 1. S-1 Nuclease digestion of OL-1 to OL-3 
The addition of MMLV- RT to ${ }^{32} \mathrm{P}$ labeled dumbbell oligomers resulted in the appearance of slow migrating species due to protein -oligonuclotide complexes formation. The oligonucleotide amount in free and bound form was determined by scintillation counting. Figure 2 shows that OL-3 bound more strongly than OL-1 and OL-2. The binding in all the three cases reached to saturation suggesting specific binding of small dumbbell oligonucleotides to a particular site of the enzyme.

We next compared the inhibitory properties of dumbbell oligonucleotides on RNase $\mathrm{H}$ activity. As shown in Figure 3, substantial difference was observed. OL-3 was far better inhibitor than OL-1 and OL-2. The sequence, design of the oligonucleotides, $\mathrm{Kd}$ and \% RNase $\mathrm{H}$ activity inhibition are tabulated in Table 1.

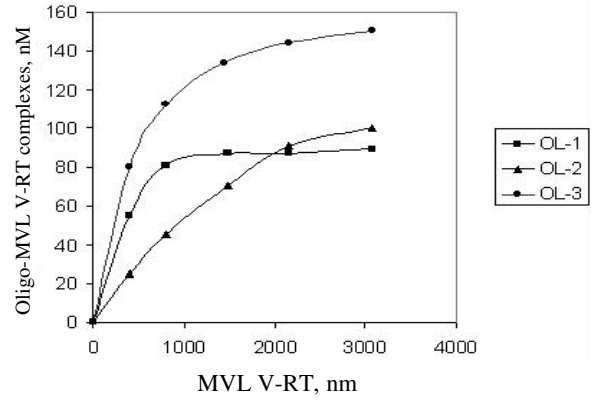

Figure 2. Binding curves of MMLV RT to small dumbbell oligonucleotides

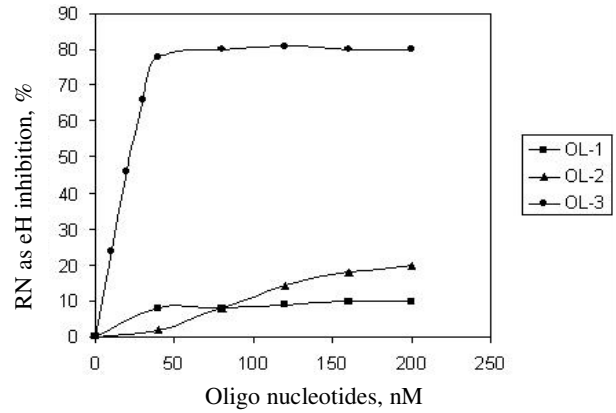

Figure 3. Inhibition of RNase $\mathrm{H}$ activity of MMLV RT by small dumbbell oligonucleotides

The dissociation constant of OL-3 with RT evaluated from the titration curve fall in the micro molar range (Table 1). The dissociation constant of OL-1 and OL-2 could not be determined as saturation reached before $50 \%$ binding.

Table 1. Sequences of small dumbbell oligonucleotides and Percentage RNase H activity inhibition

\begin{tabular}{|c|c|c|c|c|}
\hline \multirow[t]{2}{*}{ S. No } & \multirow[t]{2}{*}{ Sequences } & \multicolumn{2}{|c|}{$\begin{array}{l}\% \text { RNase } \mathrm{H} \\
\text { Inhibition at }\end{array}$} & \multirow{2}{*}{$\begin{array}{c}\mathrm{Kd}\left(\mathrm{M}^{-1}\right) \\
(\mathrm{Kd}=1 / \mathrm{Ka})\end{array}$} \\
\hline & & $200 \mathrm{nM}$ & $50 \mathrm{nM}$ & \\
\hline \multirow{3}{*}{ OL-1 } & 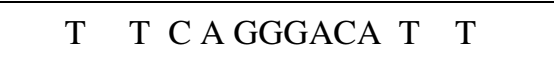 & & & \\
\hline & $\mathrm{T}$ & 17 & 10 & \\
\hline & $\mathrm{T} \quad \mathrm{T} \quad \mathrm{GTCCCTGT} \mathrm{T} \mathrm{T}$ & & & \\
\hline \multirow[t]{3}{*}{ OL-2 } & $\underset{P}{\mathrm{C}_{3} \mathrm{C}}$ A G G G A C A $\mathrm{C}_{3}$ & 25 & 2 & \\
\hline & $\mathrm{C}_{3} \mathrm{G} \quad \mathrm{T} \quad \mathrm{C} \quad \mathrm{C} \quad \mathrm{C} \quad \mathrm{T} \quad \mathrm{G} \quad \mathrm{Tll}_{3}$ & & & \\
\hline & $\mathrm{s} T \mathrm{~s} T \mathrm{~s} C \mathrm{~A}$ GGGAC A s T s $\mathrm{T}$ & & & \\
\hline \multirow{4}{*}{ OL-3 } & $\mathrm{T}$ & & & \\
\hline & $\mathrm{T}$ & & & \\
\hline & Ts Ts G TCC C T T sTs Ts & 80 & 80 & $5.3 \times 10^{-7}$ \\
\hline & $\begin{array}{l}\text { s denotes phosphorothioate linkage in } \\
\text { the loops }\end{array}$ & & & \\
\hline
\end{tabular}


From the above studies it appears that the properties of these dumbbell oligonucleotides were mainly related to loop chemistry. The oligonucleotide's loop might interact with the catalytic site of the enzyme, preferably with the loops of the RNase $\mathrm{H}$ domain of the reverse transcriptase. The OL- 3 bound more strongly with reverse transcriptase and was also a far better inhibitor of RNase $\mathrm{H}$ activity than OL-1 and OL-2. The phosphorothioate oligonucleotides have been shown to inhibit RNase $\mathrm{H}$ activity ${ }^{21}$. Therefore this interesting observation suggests that small dumbbell oligonucleotides containing phosphorothioate linkage (six on both sides) in the loops portion, such as OL-3, could be used as RNase H inhibitor at as low as $60 \mathrm{nM}$ concentration and might be useful to interfere with retroviral cDNA synthesis. Our studies showed that small dumbbell oligonucleotide (containing $8 \mathrm{bp}$ duplex in the center and phosphorthioate linkages in both the loops) displays an $\mathrm{IC}_{50}$ of $25 \mathrm{nM}$ in its inhibition on the reverse transcriptase RNase $\mathrm{H}$ activity, equal to that of dumbbell oligonucleotide (containing 12 bp duplex in the center and phosphorothioate linkages in both the loop). From this it can be concluded that dumbbell oligonucleotides containing $8 \mathrm{bp}$ duplex in the center of the dumbbell can bind to the reverse transcriptase as effectively as 12 bp containing dumbbell oligonucleotides ${ }^{16}$. Our studies clearly showed that small dumbbell oligonucleotide containing phosphorthioate bonds in the loops displays an $\mathrm{IC}_{50}$ of $25 \mathrm{nM}$ in its inhibition on the reverse transcriptase RNase $\mathrm{H}$ activity, a magnitude lower than that of first nucleotide reverse transcriptase of HIV-1, tenofovir, introduced by Gilead Science in the market. Therefore, this investigation suggests that dumbbell oligonucleotide containing phosphorothioate linkages can be used as RNase $\mathrm{H}$ inhibitor and might be useful to interfere with retroviral cDNA synthesis.

\section{References}

1. Champoux J J, Reverse Transcriptase, Skalka A M and Golf S P (Eds): Cold Spring Harbor Laboratory Press, Cold Spring Harbor, 1993, 103.

2. Hostomsky Z, Hostomska Z and Mathews D A. In Nucleases, Cold Spring Harbor Laboratory Press, 1993, 341-376.

3. Morgolis D, $14^{\text {th }}$ CROI Conference on Retrovirus and Opportunistic Infections, Los Angels, Feb 25- 28, 2007.

4. Borkow G, Fletcher R S, Barnard J, Arion D, Motakis D, D,itrienko G I and Parniak M A, Biochem., 1997, 36, 3179.

5. Loya S, Tal R, Kashman Y and Hizi A, Antimicrob Angents Chemother., 1990, 34(10), 2009-2012.

6. Loya S and Hizi A, J Biol Chem., 1993, 268, 9323-9328.

7. Shaw - Reid C A, Munshi V, Graham P, Wolfe A, Witner M, Danzeisen R, Olsen D B, Carroll S S, Embrey M, Wai J S, Miller M D, Cole J L and Hazuda D J, J Biol Chem., 2003, 278, 2777-2780.

8. Wasner M, Arion D, Borkow G, Nornha A, Uddin A H, Parniak M A and Damha M J, Biochem., 1998, 37, 7478-7486.

9. Gamper H B, Reed M W, Cox T, Virosco J S, Adams A D, Gall A A, Scholler J K and Meyer R B J, Nucl Acids Res., 1993, 21(1), 145.

10. Hannoush R N, Carriero S , Min K L, Damha M J, Chem Biochem., 2004, 5 , 527-533.

11. Hannoush R N, Min K L and Damha M J, Nucleic Acids Res., 2004, 32(21), 6164-6175 and references therein.

12. Agarwal S, Trends in Biotechnlgy, 1996, 14(10), 376-387.

13. Hybridon News Release, July 25, 1997.

14. Nichols W G and Boeckh M, J Clin Virol, 2000, 16(1), 25-40. 
15. Clusel C, Ugarte E, Enjolras N, Vasseur M and Blumenfeld M, Nucl Acids Res., 1993, 21, 3405.

16. Ajay Kumar, E - J Chem., 2010, 7(3), 701-708.

17. Iyer P R, Lawrence L R, Egan W, Regan J B and Beaucage S L, J Org Chem., 1990, 55, 4693.

18. Boiziau C, Larrouy B, Sproat B and Toulme J J, Nucleic Acids Res., 1995, 23, 64-71.

19. Cazenave C. Frank P and Busen W, Biochimie, 1993, 75, 113-122.

20. Verspieren P, Cornelissen A W C A, Thuong N T, Helene C and Toulme J J, Gene 1987, 61, 307-315.

21. Gao W Y, Han F S, Strom C, Egan W and Cheng M Y C, Mol Pharmacol., 1992, 41(2), 223-229. 


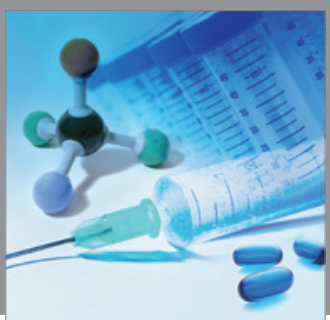

International Journal of

Medicinal Chemistry

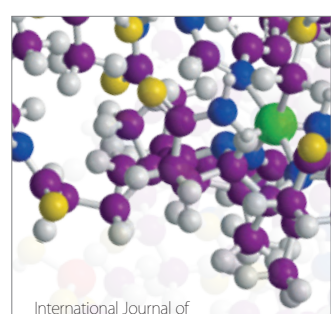

Carbohydrate Chemistry

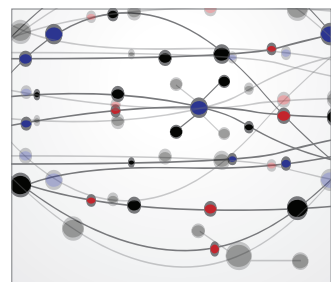

The Scientific World Journal
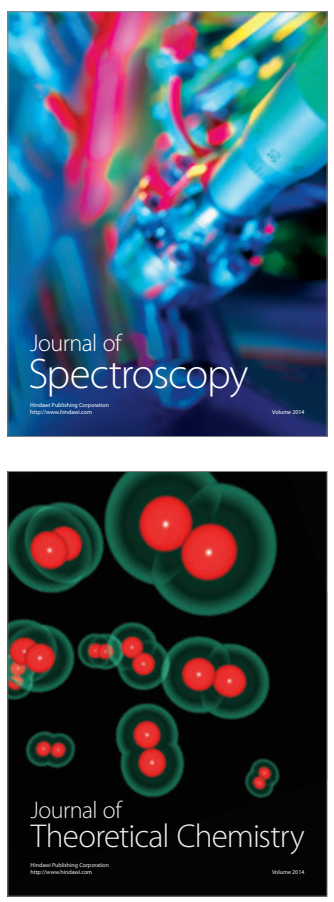
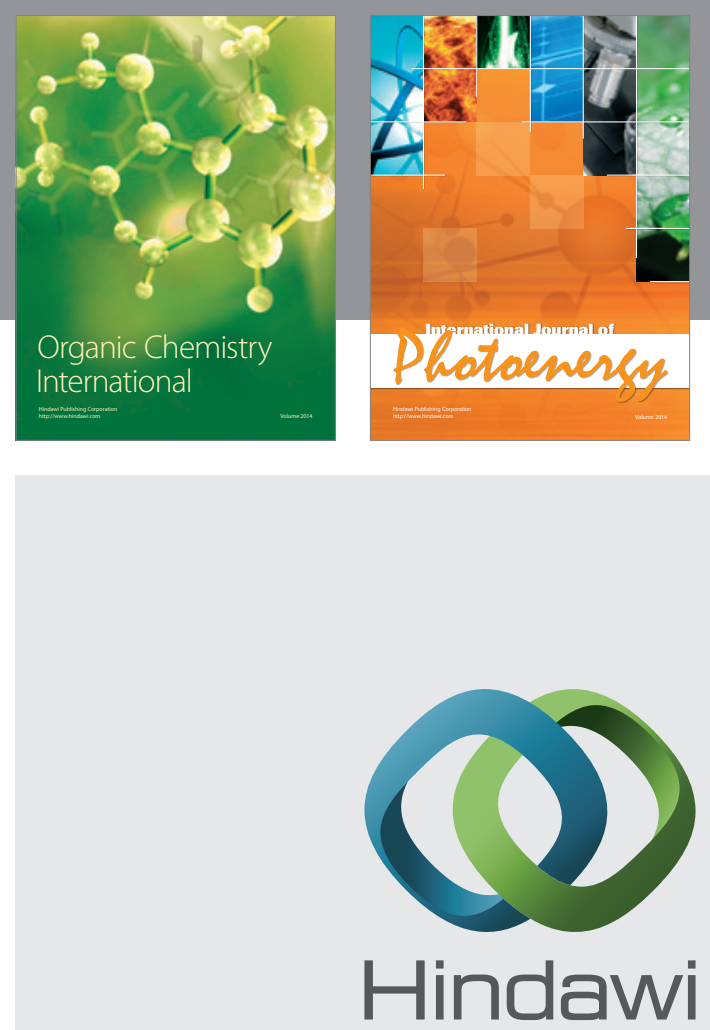

Submit your manuscripts at

http://www.hindawi.com
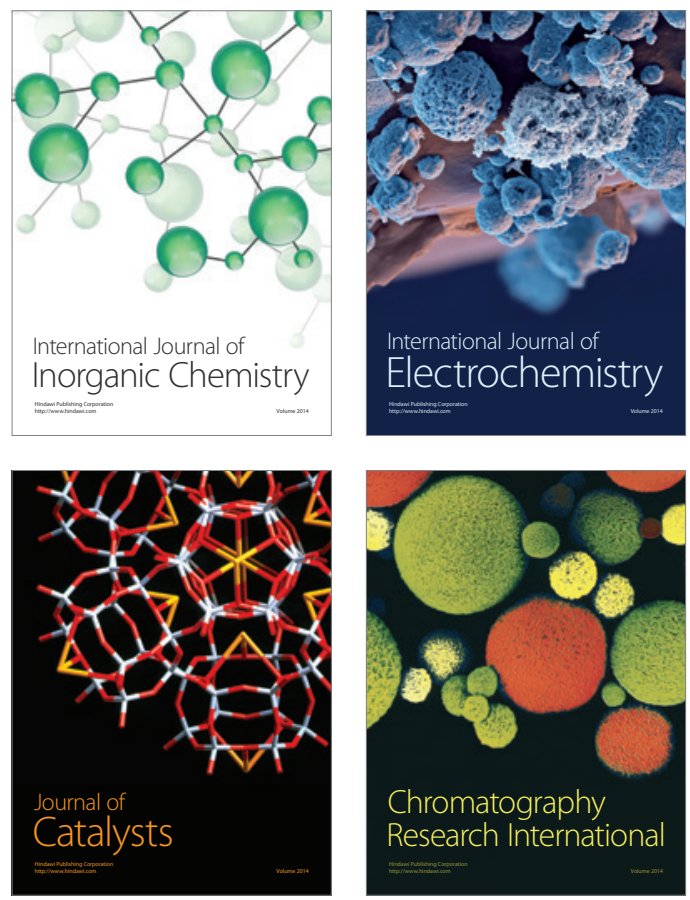
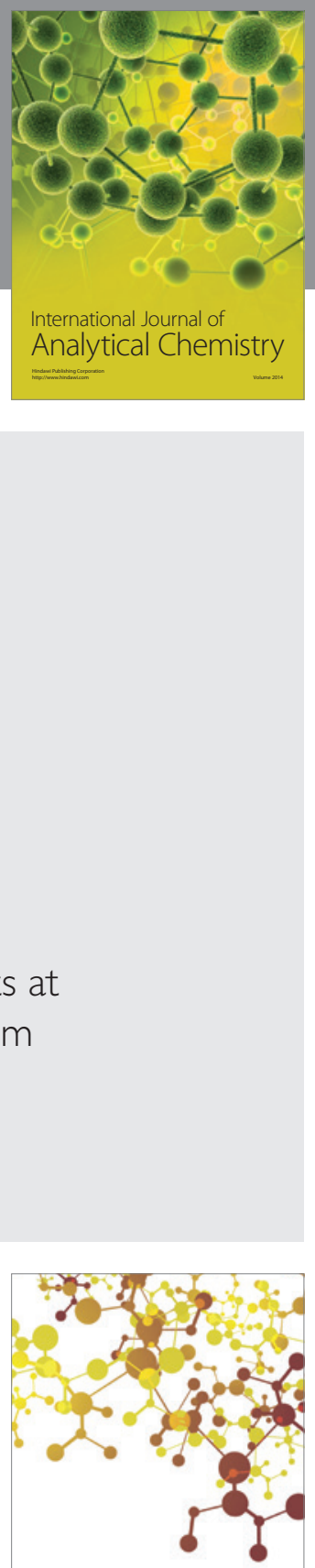

Journal of

Applied Chemistry
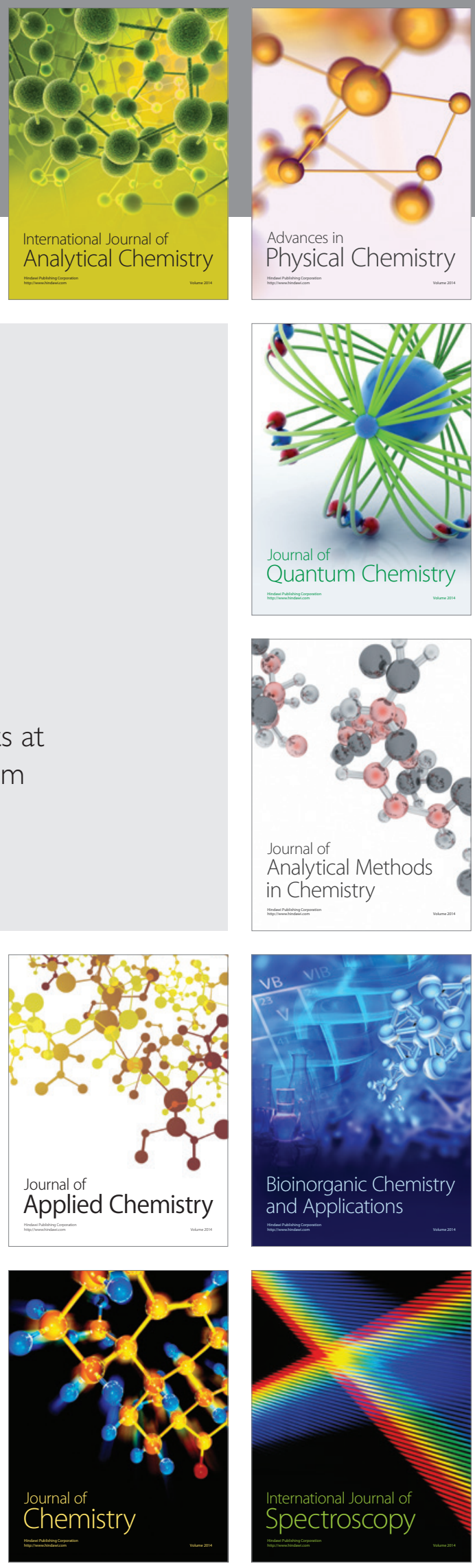